\title{
Studies on Fungal and Bacterial Population of Air- conditioned Environments
}

\author{
Claudia Ross ${ }^{1}$, Jose Roberto de Menezes ${ }^{1}$, Terezinha Inez Estivalet Svidzinski ${ }^{2}$, Ulisses \\ Albino $^{1}$ and Galdino Andrade ${ }^{1 *}$ \\ ${ }^{1}$ Universidade Estadual de Londrina; CCB; Departamento de Microbiologia; Laboratório de Ecologia Microbiana; \\ C. P. 6001; andradeg@uel.br; 86051-990; Londrina - PR - Brazil. ${ }^{2}$ Universidade Estadual de Maringá; \\ Departamento de Análises Clínicas; Laboratório de Microbiologia Clínica; Campus Universitário; 87020-600; \\ Maringá - PR - Brazil
}

\begin{abstract}
In tropical countries such as Brazil, there is not enough information about microbial contaminants in indoor environments with air conditioning systems. Microbial monitoring of such environments is important for the quality of human life. The aim of this work was to assess the fungal genera and bacterial morphotypes occurring in such environments. Air samples were taken indoors and outdoors from a public auditorium, a hospital, a company and a shopping center during the 2001 winter by using a six-stage impactor Millipore M air $T^{\circledR}$. Twenty-one fungal genera were identified. Bacterial morphological groups found were Gram positive and negative rods and Gram positive coccus.
\end{abstract}

Key words: Sick building syndrome, fungi, bacteria, air conditioner, indoor air quality, air ecology

\section{INTRODUCTION}

The aim of air conditioning systems is to provide occupants with a more comfortable environment. Nevertheless, such artificial environments may be favorable to fungi, bacteria, protozoan and mites growth, which may bring health risks to users, either by hypersensitivity or infections (Morey et al., 1986; Vincent et al., 1997; Cooley et al., 1998). According to the American Society of Heating, Refrigerating and Air Conditioning Engineers (ASHARAE, 2000), the health effects caused by microorganisms that are in indoor environments with air conditioning systems can be infective or immunological.

The term sick building syndrome (SBS) is commonly used for health disturbances related to indoor air quality (IAQ). Lack of cleaning and checking out of the heating, ventilation and air conditioning systems (HVAC) may allow microbial growth, which causes rhinitis, bronchitis, pharyngitis, pneumonia, conjunctivitis and keratitis in the users. According to ASHARAE (2000), if $20 \%$ or more users of such environments present the above-mentioned symptoms, these places are considered under SBS. It must be stressed that several other factors may aggravate SBS, including outdoor air quality, air insufficiency or bad air distribution, inefficient control of air temperature and humidity, improper project or changes in the original building project and lack of monitoring, checking out and cleaning of HVAC systems.

\footnotetext{
* Author for correspondence
} 
SBS probably has a multi-factorial etiology with chemical, physical, biological and psychosocial factors that interact with each other, resulting in symptoms and discomfort (Baker, 1989; Norback et al., 1990). Thus, SBS may influence public health and economy negatively, because some of these diseases decrease workers' productivity and cause their absence at work.

Indoor air quality effects on health and the large use of HVAC systems in indoor environments reinforce the importance to reproduce and standardize methods for microbial monitoring in such indoor environments. For tropical countries, microbial assessment of environments with HVAC systems is even more important due to the high microbial biodiversity associated with high temperature and relative air humidity, favoring microbial growth. The objective of this study was to determine the fungal community and bacterial levels in four sites that use HVAC systems.

\section{MATERIAL AND METHODS}

\section{Experimental design}

The present work had the following experimental design: four sites (a public auditorium, a hospital, a company and a shopping center), two types of air samples indoor air (AIM) and outdoor air (AOM), both collected by impactor $\mathrm{M}$ air $\mathrm{T}^{\circledR}$ in five replicates for each sample, distributed as fixed point in each collecting place.

\section{Samples}

The collecting of the samples was conducted in the winter of 2001, in the city of Londrina, PR, Southern of Brazil. During this season, there is wide use of environment insulation, which probably increases the number of bioaerosols in indoor air, coinciding with high levels of respiratory infections. A six-stage impactor Millipore M Air $\mathrm{T}^{\circledR}$ collected the samples, so that the air was impacted in Petri dishes containing specific medium for fungi and bacteria, as well as appropriate design for equipment use (cassettes $M$ Air $\mathrm{T}^{\circledR}$ ). During the collection, the air sampler remained about one meter above floor level.

Each sample collected with the impactor Millipore M Air $\mathrm{T}^{\circledR}$ contained $100 \mathrm{~L}$ of air for fungi and $1000 \mathrm{~L}$ for bacteria. All the collection patterns (time of air impactation, culture medium, agar concentration, season of the year, sites and collection points) have been determined in previous experiments.

\section{Isolation and taxonomic study of fungi}

For inoculation through air sample impactation, the culture medium was semi-solid malt extract agar (malt extract $20 \mathrm{~g}$, glucose $20 \mathrm{~g}$, peptone $2 \mathrm{~g}$, agar $7 \mathrm{~g}, \mathrm{dH}_{2} \mathrm{O} 1000 \mathrm{~mL}, \mathrm{pH} 5.5$ ), being that the dishes were incubated for 5 days at $28^{\circ} \mathrm{C}$. The number of fungi colonies present was assessed in the third and fifth days of incubation, and the number of colony forming units was determined per $\mathrm{m}^{3}$ of air (CFU m${ }^{-3}$ air). After that, the colonies considered morphologically distinct were isolated and again compared with each other, so that only one isolated strain representative of each morphological group found was selected. The representative strains were preserved at room temperature in sealed glasses with paraffin, containing sterile saline $(0.85 \% \mathrm{NaCl})$ and agar plates obtained from the culture of each fungus.

The taxonomic identification of fungi was performed considering the morphological characteristics of the vegetative mycelium and the reproductive structures (Barnett and Hunter, 1972; Koneman and Roberts, 1992; Hoog and Guarro, 1995; Larone, 1995; Ainsworth et al., 1995; Silveira, 1995; Alexopoulos et al., 1996; Lacaz et al., 1998).

Some fungi strains had poor growth or did not showed any reproductive structures in the initial conditions of cultivation, this strains were submitted to different culture conditions, such as temperature, exposure to black light UV, sun light and incubation time and others culture media such as Sabouraud Dextrose agar (casein peptone $5 \mathrm{~g}$, meat peptone $5 \mathrm{~g}$, glucose $40 \mathrm{~g}$, agar $15 \mathrm{~g}, \mathrm{dH}_{2} \mathrm{O}$ $1000 \mathrm{~mL}, \mathrm{pH}=5.6$ ), Potato Dextrose agar (potato extract $4 \mathrm{~g}$, glucose $20 \mathrm{~g}$, agar $15 \mathrm{~g}, \mathrm{dH}_{2} \mathrm{O} 1000$ $\mathrm{mL}, \mathrm{pH}=5.6$ ) and agar $\mathrm{V} 8$ (juice $\mathrm{V} 8200 \mathrm{~mL}$, $\mathrm{CaCO}_{3} 3 \mathrm{~g}$, agar $15 \mathrm{~g}, \mathrm{dH}_{2} \mathrm{O} 800 \mathrm{~mL}, \mathrm{pH}=6.2$ ) and incubated at temperatures 20,22, 24, 26 e $28^{\circ} \mathrm{C}$ and at room temperature from 7 to 10 days.

\section{Isolation and morphological study of bacteria}

For bacteria study was used Tryptic Soy agar plus Benlate (casein peptone $17 \mathrm{~g}$, soy peptone $3 \mathrm{~g}$, dextrose $2.5 \mathrm{~g}$, sodium chloride $5 \mathrm{~g}$, dibasic potassium phosphate $2.5 \mathrm{~g}$, agar $15 \mathrm{~g}$, Benlate 20 $\mathrm{mg} ; \mathrm{dH}_{2} \mathrm{O} 1000 \mathrm{~mL}, \mathrm{pH}=6.2$ ). After the air samples inoculation, the Petri dishes were incubated for three days at $28^{\circ} \mathrm{C}$. The number of 
bacteria colonies were assessed in the first and third days of incubation, and the number of CFU $\mathrm{m}^{-3}$ air was determined. Following that, the colonies considered morphologically distinct were isolated and compared with each other again, being that only one isolated strain representative of each morphological group found was selected. The representative strains were stored at $-70^{\circ} \mathrm{C}$ in glycerin $20 \%$.

For the study of the morphological groups, the strains was stained by Gram method and examined by microscopic and morphological characteristics of the bacterial cells was evaluated, ordering them in positive and negative Gram rods and coccus.

\section{RESULTS}

\section{Fungi}

The number of CFU of fungi in the samples of AIM was smaller in the public auditorium and in the hospital and bigger in the shopping center and in the company. On the other hand, for the AOM samples, the number of CFU showed differences only on the air of hospital, was smaller than other sites. It has been observed that in all the sites the outdoor air had a bigger number of CFU of fungi when compared with the indoor air. The ratio AIM:AOM of CFU of fungi for the different sites analyzed also showed differences, being smaller in the public auditorium and bigger in the company (Table 1).

Table 1 - Ratio between indoor and outdoor number of fungi colony forming unit (CFU m ${ }^{-3}$ air) collected by stage air impactor Millipore $\mathrm{M}$ Air $\mathrm{T}^{\mathrm{TM}}$. $\mathrm{AIM}=$ air indoor sample; $\mathrm{AOM}=$ air outdoor sample; $\mathrm{I}: \mathrm{O}=$ ratio between indoor and outdoor samples. The values represent means of five replications and the Standard Error (SE) was estimated by sample from each place.

\begin{tabular}{|c|c|c|c|c|}
\hline \multirow{2}{*}{ Samples } & Public Auditorium & Hospital & Company & Shopping Center \\
\hline & CFU fungi $\mathrm{m}^{-3}$ air & CFU fungi $\mathrm{m}^{-3}$ air & CFU fungi $\mathrm{m}^{-3}$ air & CFU fungi $\mathrm{m}^{-3}$ air \\
\hline AIM & 178 & 194 & 312 & 338 \\
\hline $\mathrm{SE}$ & 58.86 & 39.45 & 36.80 & 38.00 \\
\hline $\mathrm{AOM}$ & 507 & 338 & 454 & 526 \\
\hline $\mathrm{SE}$ & 85.32 & 29.90 & 43.66 & 29.43 \\
\hline $\mathrm{I}: \mathrm{O}^{\mathrm{a}}$ & 0.35 & 0.57 & 0.69 & 0.64 \\
\hline
\end{tabular}

The genera Aspergillus and Epicoccum were found in all the AIM and AOM air samples of the four sites. The genera Penicillium was found in all AIM samples but in the AOM samples this genera was not found in the shopping center samples. Among the three most common fungi found, the population of Aspergillus was biggest in all the AIM and AOM samples, except for the public auditorium. The biggest number of the Penicillium population was observed in the AIM air samples, and the genera Aspergillus and Epicoccum in the AOM air samples (Table 2). In the AIM samples the genus Alternaria was found only in the public auditorium and AOM in all the samples of the four sites. Others genera found such as Botrytis, Chrysosporium, and Cladosporium, Leptosphaeria [doubtful], Mucor, Neurospora, Phoma, Rhizopus, Trichoderma and Verticillium were found only in
AOM samples. On the other hand, some fungi were found in a few AIM samples, in this way, the Microsporum was observed only in the AIM air of the hospital. The genus Fusarium was not found either in the public auditorium or in the hospital. The genera Emmonsia did not occur in the company and the Myriodontium [doubtful] in the hospital. The genus Curvularia was found in AOM samples of the public auditorium and in the AIM of the company and the shopping center. The genus Acremonium, occurred in the AIM and AOM samples of the public auditorium and in the AOM samples of the shopping center. Nonidentified fungi were found in the AIM and AOM samples of the four analyzed sites, because it was not possible to obtain reproductive structures in the several conditions tested (Table 2). 
Table 2 - Number of colony forming unit (CFU $\mathrm{m}^{-3}$ air) of fungi isolated from air of indoor (AIM) and outdoor $(\mathrm{AOM})$ at differents locals discrimined between genera. Air samples were collected by stage air impactor Millipore M Air TTM.

\begin{tabular}{|c|c|c|c|c|c|c|c|c|}
\hline \multirow{2}{*}{ Genera } & \multicolumn{2}{|c|}{ Public Auditorium } & \multicolumn{2}{|c|}{ Hospital } & \multicolumn{2}{|c|}{ Company } & \multicolumn{2}{|c|}{$\begin{array}{c}\text { Shopping } \\
\text { Center }\end{array}$} \\
\hline & AIM & AOM & AIM & AOM & AIM & AOM & AIM & AOM \\
\hline Acremonium & 2 & 1 & - & - & - & - & - & 4 \\
\hline Alternaria & 6 & 50 & - & 8 & - & 30 & - & 22 \\
\hline Aspergillus & 20 & 76 & 100 & 78 & 186 & 198 & 186 & 234 \\
\hline Brotrytis & - & 3 & - & 2 & - & - & - & - \\
\hline Chrysosporium & - & 3 & - & 8 & - & - & - & 8 \\
\hline Cladosporium & - & 3 & - & - & - & 6 & - & 6 \\
\hline Curvularia & - & 2 & - & - & 2 & - & 2 & - \\
\hline Drechslera & - & - & 4 & - & 4 & - & 18 & - \\
\hline Emmonsia & 2 & - & 4 & - & - & - & 6 & - \\
\hline Epicoccum & 10 & 98 & 2 & 44 & 4 & 86 & 12 & 70 \\
\hline Fusarium & 4 & - & 2 & - & - & - & - & - \\
\hline Leptosphaeria (doubtful) & - & 153 & - & 116 & - & 64 & - & 70 \\
\hline Microsporum & - & - & 6 & - & - & - & - & - \\
\hline Mucor & - & 24 & - & 14 & - & 20 & - & 42 \\
\hline Myriodontium (doubtful) & 4 & - & - & - & 16 & - & 2 & - \\
\hline Neurospora & - & 17 & - & 2 & - & 34 & - & 2 \\
\hline Penicillium & 102 & 45 & 62 & 4 & 64 & 2 & 68 & r- \\
\hline Phoma & - & 7 & - & 48 & - & 8 & - & 24 \\
\hline Rhizopus & - & - & - & - & - & - & - & 10 \\
\hline Trichoderma & - & 18 & - & 8 & - & 6 & - & 32 \\
\hline Verticillium & - & 4 & - & 6 & - & - & - & - \\
\hline Not identified & 28 & 3 & 14 & - & 36 & - & 44 & 2 \\
\hline Total (CFU fungi $\mathrm{m}^{-3}$ air) & 178 & 507 & 194 & 338 & 312 & 454 & 338 & 526 \\
\hline
\end{tabular}

The relative frequency of fungi varied according to the genera, sites and samples. The genera that occurred most in the public auditorium were, in decreasing order, in the AIM samples Penicillium (57.3\%), Aspergillus (11.24\%) and Epicoccum (5.63\%); as for the AOM samples, Leptosphaeria [doubtful] (30.18\%), Epicoccum (19.33\%) and Aspergillus (14.99\%). In the hospital, in the AIM samples the genera were Aspergillus (51.56\%), Penicillium (31.96\%), Microsporum (3.09\%), Emmonsia (2.06\%), and Drechslera (2.06\%); and in the AOM samples the genera Leptosphaeria [doubtful] (34.31\%), Aspergillus (23.08\%), Phoma (14.2\%) and Epicoccum (13.02\%), Mucor (4.14\%), Alternaria (2.37\%), Trichoderma (2.37\%) and Chrysosporium (2.37\%). In the company, the most frequent fungi genera in the AIM were Aspergillus (59.62\%), Penicillium
(20.51\%), and Myriodontium [doubtful] (5.13\%), and in the AOM samples, Aspergillus (43.61\%), Epicoccum (18.94\%), Leptosphaeria [doubtful] (14.1\%), Neurospora (7.49\%), and Alternaria $(6.61 \%)$. In the shopping center there was predominance of the genera Aspergillus (55.02\%), Penicillium (20.12\%), Drechslera (5.33\%), and Epicoccum (3.55\%) in the AIM samples, and the genera Aspergillus (44,5\%), Epicoccum (13,31\%), Leptosphaeria [doubtful] (13.31\%), Mucor (7.98\%), Trichoderma (6.08\%), Phoma (4.56\%), and Alternaria (4.18\%) in the AOM samples. The relative values for the strains of genera represented in brackets were calculated based on the total number of fungi of both the AIM and AOM samples (Table 3). 
Table 3 - Fungal community isolated from indoor air samples (AIM) and outdoor (AOM) in differents locals, represented by percentage of each genera. Air samples were collected by stage air impactor Millipore M Air T ${ }^{\mathrm{TM}}$.

\begin{tabular}{|c|c|c|c|c|c|c|c|c|}
\hline \multirow{2}{*}{ Genera } & \multicolumn{2}{|c|}{$\begin{array}{c}\text { Public } \\
\text { Auditorium }\end{array}$} & \multicolumn{2}{|c|}{ Hospital } & \multicolumn{2}{|c|}{ Company } & \multicolumn{2}{|c|}{$\begin{array}{c}\text { Shopping } \\
\text { Center }\end{array}$} \\
\hline & AIM & AOM & AIM & AOM & AIM & AOM & AIM & AOM \\
\hline Acremonium & 1.12 & 0.2 & - & - & - & - & - & 0.76 \\
\hline Alternaria & 3.37 & 9.86 & - & 2.37 & - & 6.61 & - & 4.18 \\
\hline Aspergillus & 11.24 & 14.99 & 51.56 & 23.08 & 59.62 & 43.61 & 55.02 & 44.5 \\
\hline Brotrytis & - & 0.59 & - & 0.59 & - & - & - & - \\
\hline Chrysosporium & - & 0.59 & - & 2.37 & - & - & - & 1.52 \\
\hline Cladosporium & - & 0.59 & - & - & - & 1.32 & - & 1.14 \\
\hline Curvularia & - & 0.4 & - & - & 0.64 & - & 0.59 & - \\
\hline Drechslera & - & - & 2.06 & - & 1.28 & - & 5.33 & - \\
\hline Emmonsia & 1.12 & - & 2.06 & - & - & - & 1.78 & - \\
\hline Eрісоссит & 5.63 & 19.33 & 1.03 & 13.02 & 1.28 & 18.94 & 3.55 & 13.31 \\
\hline Fusarium & 2.25 & - & 1.03 & - & - & - & - & - \\
\hline Leptosphaeria (doubtful) & - & 30.18 & - & 34.31 & - & 14.1 & - & 13.31 \\
\hline Microsporum & - & - & 3.09 & - & - & - & - & - \\
\hline Mucor & - & 4.73 & - & 4.14 & - & 4.41 & - & 7.98 \\
\hline Myriodontium (doubtful) & 2.25 & - & - & - & 5.13 & - & 0.59 & - \\
\hline Neurospora & - & 3.35 & - & 0.59 & - & 7.49 & - & 0.38 \\
\hline Penicillium & 57.3 & 8.88 & 31.96 & 1.18 & 20.51 & 0.44 & 20.12 & - \\
\hline Phoma & - & 1.38 & - & 14.2 & - & 1.76 & - & 4.56 \\
\hline Rhizopus & - & - & - & - & - & - & - & 1.9 \\
\hline Trichoderma & - & 3.55 & - & 2.37 & - & 1.32 & - & 6.08 \\
\hline Verticillium & - & 0.79 & - & 1.78 & - & - & - & - \\
\hline Not identified & 15.72 & 0.59 & 7.21 & - & 11.54 & - & 13.02 & 0.38 \\
\hline Total (\%) & 100 & 100 & 100 & 100 & 100 & 100 & 100 & 100 \\
\hline
\end{tabular}

Table 4 - Ratio between indoor and outdoor number of bacteria colony forming unit (CFU m${ }^{-3}$ air) collected by stage air impactor Millipore $\mathrm{M}$ Air $\mathrm{T}^{\mathrm{TM}}$. $\mathrm{AIM}=$ air indoor; $\mathrm{AOM}=$ air outdoor; $\mathrm{I}: \mathrm{O}=$ ratio between indoor and outdoor. The values represent means of five replications and Standard Error (SE) was estimated by sample from each place.

\begin{tabular}{|c|c|c|c|c|}
\hline \multirow{2}{*}{ Samples } & Public Auditorium & Hospital & Company & Shopping Center \\
\hline & CFU bacteria $\mathrm{m}^{-3}$ air & CFU bacteria $\mathrm{m}^{-3}$ air & CFU bacteria $\mathrm{m}^{-3}$ air & CFU bacteria $\mathrm{m}^{-3}$ air \\
\hline AIM & 16.20 & 54.60 & 67.60 & 84.40 \\
\hline SE & 4.82 & 6.73 & 7.65 & 8.51 \\
\hline $\mathrm{AOM}$ & 38.60 & 41.00 & 93.00 & 104.60 \\
\hline SE & 8.71 & 4.84 & 4.39 & 4.38 \\
\hline I:Ao & 0.42 & 1.33 & 0.73 & 0.81 \\
\hline
\end{tabular}

${ }^{\mathrm{a}}$ The values from indoor and outdoor ratio of number of bacteria colony forming unit (CFU m ${ }^{-3}$ air), $\mathrm{I}: \mathrm{O}=<1.5$ environment in proper condition; $\mathrm{I}: \mathrm{O}=1.5$ a 2 environment regular condition; $\mathrm{I}: \mathrm{O}=>2$ environment not proper condition.

\section{Bacteria}

The number of CFU of total bacteria in the AIM and AOM samples from the different sites was smaller in the public auditorium and in the hospital, and bigger in the shopping center and in the company. When compare the number of CFU 
indoor and outdoor, was observed that only in the hospital, AOM population was smallest than AIM air samples. The ratio AIM:AOM concerning the number of bacteria CFU in the different sites analyzed also showed differences, being smaller in the public auditorium and bigger in the hospital (Table 4).In the indoor air samples there was predominance of Gram positive rods for the public auditorium, hospital and shopping center, except for the company, where Gram positive coccus was predominant. For the outdoor air samples, predominance of Gram negative rods was observed in all the sites (Table 5).

Table 5 - Number of colony forming unit (CFU m ${ }^{-3}$ air) of bacteria isolated from air of indoor (AIM) and outdoor (AOM) at differents locals discrimined between morphological group. Air samples were collected by stage air impactor Millipore M Air T ${ }^{\mathrm{TM}}$.

\begin{tabular}{ccccccccc}
\hline & \multicolumn{2}{c}{$\begin{array}{c}\text { Public } \\
\text { Morphological group }\end{array}$} & \multicolumn{2}{c}{ Hospital } & \multicolumn{2}{c}{ Company } & \multicolumn{2}{c}{$\begin{array}{c}\text { Shopping } \\
\text { Center }\end{array}$} \\
\cline { 2 - 8 } & AIM & AOM & AIM & AOM & AIM & AOM & AIM & AOM \\
\hline Gram-positive coccus & 3.60 & 3.10 & 19.00 & 6.20 & 34.40 & 17.20 & 32.60 & 21.80 \\
Gram-positive rods & 9.60 & 3.40 & 22.00 & 9.00 & 16.20 & 11.00 & 37.80 & 13.20 \\
Gram-negative rods & 3.00 & 32.10 & 13.60 & 25.80 & 17.00 & 64.80 & 14.00 & 69.60 \\
Total (CFU m ${ }^{-3}$ air) & 16.20 & 38.60 & 54.60 & 41.00 & 67.60 & 93.00 & 84.40 & 104.60 \\
\hline
\end{tabular}

Table 6 - Bacteria community isolated from indoor air samples (AIM) and outdoor (AOM) in differents locals, represented by percentage of each morphological group. Air samples were collected by stage air impactor Millipore M Air T TM.

\begin{tabular}{lcccccccc}
\hline \multirow{2}{*}{ Morphological group } & \multicolumn{2}{c}{$\begin{array}{c}\text { Public } \\
\text { Auditorium }\end{array}$} & \multicolumn{2}{c}{ Hospital } & \multicolumn{2}{c}{ Company } & \multicolumn{2}{c}{$\begin{array}{c}\text { Shopping } \\
\text { Center }\end{array}$} \\
\cline { 2 - 9 } & AIM & AOM & AIM & AOM & AIM & AOM & AIM & AOM \\
\hline Gram-positive coccus & 22.22 & 8.03 & 34.80 & 15.12 & 50.89 & 18.50 & 38.63 & 20.84 \\
Gram-positive rods & 59.26 & 8.81 & 40.30 & 21.95 & 23.96 & 11.83 & 44.78 & 12.62 \\
Gram-negative rods & 18.52 & 83.16 & 24.90 & 62.93 & 25.15 & 69.67 & 16.59 & 66.54 \\
Total (\%) & 100 & 100 & 100 & 100 & 100 & 100 & 100 & 100 \\
\hline
\end{tabular}

The relative frequency varied according to the morphological group, sites and samples. In the AIM samples from the public auditorium there was predominance of Gram positive rods (59.26\%), followed by Gram positive coccus $(22.22 \%)$ and Gram negative rods (18.52\%). However, in the AOM samples there was predominance of Gram negative rods $(83.16 \%)$, followed by Gram positive rods (8.81\%) and Gram positive coccus $(8.03 \%)$. In the AIM samples of the hospital Gram positive rods predominated
(40.30\%), followed by Gram positive coccus $(34.80 \%)$ and Gram negative rods (24.90\%), whereas in the AOM samples the Gram negative rods were more frequent $(62.93 \%)$, followed by Gram positive rods $(21.95 \%)$ and Gram positive coccus $(15.12 \%)$. In the company, the most frequent morphological groups in the AIM samples were Gram positive coccus (50.89\%), followed by Gram negative rods $(25.15 \%)$ and Gram positive rods $(23.96 \%)$. In the AOM samples the highest frequency was of Gram 
negative rods $(69.67 \%)$, followed by Gram positive coccus $(18.50 \%)$ and Gram positive rods $(11.83 \%)$. In the AIM samples from the shopping center, there was predominance of Gram positive rods $(44.78 \%)$, Gram positive coccus $(38.63 \%)$ and lower occurrence of Gram negative rods $(16.59 \%)$. At the same time, in the AOM samples, the highest frequency was of Gram negative rods $(66.54 \%)$ and the lowest frequency was of Gram positive coccus $(20.84 \%)$ and Gram positive rods (12.62\%) (Table 6).

\section{DISCUSSION}

In the public auditorium, company and shopping center, both indoor and outdoor air samples showed contamination fungi below the acceptable levels, when compared with many health organization standardization. The World Health Organization (WHO, 1988) recommends until 500 CFU $\mathrm{m}^{-3}$ air, the Healthy Building International (HBI) (Rao et al., 1996) concentration less than $750 \mathrm{CFU} \mathrm{\textrm {m } ^ { - 3 }}$ air, the National Institute of Occupational Safety and Healthy (NIOSHI-USA) (Jensen and Schafer, 1998) up to $1000 \mathrm{CFU} \mathrm{m}^{-3}$ air, and the Brazilian Health Ministry (ANVISA, 2000) $750 \mathrm{CFU} \mathrm{m}{ }^{-3}$ air. Nevertheless, according to Rao et al. (1996), for qualitative indoor air evaluation, levels ranging from 100 to $1000 \mathrm{CFU}$ of fungi $\mathrm{m}^{-3}$ air could be considered. However, Jensen Yand Schafer (1998) point out that the NIOSHI-USA, in its manual of analytical methods, reinforces the fact that a low concentration of microorganisms in indoor air environments does not mean they are healthy, but needs to identify the microorganisms to evaluate the conditions of the air-conditioning systems.

For the hospital environments, the WHO (1988) recommends not more than $50 \mathrm{CFU}$ of fungi $\mathrm{m}^{-3}$ air. In this study, nevertheless, the fungal contamination levels were $194 \mathrm{CFU} \mathrm{m} \mathrm{m}^{-3}$ air for indoor samples. This level for fungal contamination is four times the WHO limit, which could result in a transmition of several diseases especially in immune-depressive patients.

In the indoor air evaluated in England and USA, the CFU of fungi were three times high than in this work, but the fungi genera were the same (Jones, 1999). The ratio AIM:AOM found in all samples was lower than 1.5 , is controversy for Brazilian regulations that consider this level as safety air, however other authors (Rao et al., 1996) considered the ratio level up to 1 the air with potential risk to occur an amplification of microbial populations such as fungi and bacteria. Probably the most common fungi isolated from indoor air environment belong to the Deutoromycota division (imperfect fungi) and the most frequently genera found are Penicillium, Aspergillus, Eurotium, Wallemia, Cladosporium and Alternaria (Wanner et al., 1993). In the present study, we found the same results, most of then were belong Deutoromycota division and the most common genera were also the same.

The Penicillium population was biggest in indoor air and Aspergillus, Epicoccum and Alternaria in outdoor air. The same results were found in a hotel (Mcgrath et al., 1999) and a school (Cooley et al., 1998) with HVAC system in the USA.

The number of bacteria in the four sites evaluated remained within the maximum acceptable microbiological limits for the quantitative patterns considered. According to Morey et al. (1986) the American Conference of Governmental Industrial Hygienists (ACGIH) has as pattern that the concentration of de Bacillus $s p$. and Gram negative bacteria should not over $500 \mathrm{CFU} \mathrm{\textrm {m } ^ { - 3 }}$ air. According to The HBI (Rao et al., 1996), they considers that concentrations lower than $750 \mathrm{CFU}$ $\mathrm{m}^{-3}$ air of viable bacteria indicate that the building is free contamination if there are not infectious or allergenic species.

These values, however, are controversial, since there is a great variation as to what is considered adequate by different authors. Toth (1992) suggests that the counting of human normal flora bacteria above $200 \mathrm{CFU} \mathrm{m} \mathrm{m}^{-3}$ air be considered high. On the other hand, Hood (1990) states that $500 \mathrm{CFU} \mathrm{m}^{-3}$ air of Gram negative bacteria is sufficient to suspect of problems in the indoor air quality. For hospital environments, the maximum number of bacteria CFU allowed by the WHO (1988) is $100 \mathrm{CFU} \mathrm{m}^{-3}$ air. In the indoor air samples, the values do not surpass $100 \mathrm{CFU}$.

The air samples evaluated from home and school in England and USA (Jones, 1999) had nine times more bacteria than found in this study in the places evaluated. But (Li et al., 2001) evaluating many shopping centers in Hong Kong found different bacteria levels on the weekend when the number of people inside the building increased.

Aeroecology of indoor air environments among differents countries around the world showed that the fungi genera found in these places generally are the same. However the number of CFU is high 
in template zone when compared with tropical zone. The homogenized community that are living in the indoor air certainly does not correspond that what occur in the outdoor air environments, when the focus is biodiversity and size of population in a tropical and template zones, this fact should indicate that the human activity is building an artificial ecosystem, that can be favoring some genera of hazardous microorganisms and increase the risk of health inside the building.

\section{ACKNOWLEDGEMENTS}

To the National Council of Scientific and Technological Development Brazil (CNPq) for awarding the Master's and Research Productivity Grant. To the Coordination of Improvement of Tertiary Level Students Brazil (CAPES) for the financial support.

\section{RESUMO}

Em países tropicais como o Brasil, não há informação suficiente sobre contaminantes microbianos em ambientes internos com sistemas de ar condicionado. Monitoramento microbiano em tais ambientes é importante para a qualidade de vida humana. $\mathrm{O}$ objetivo deste trabalho foi identificar os gêneros de fungos e morfotipos de bactérias que ocorrem em tais ambientes. Amostras de ar foram coletadas dentro e fora de um auditório público, um hospital, uma empresa e um shopping center durante o inverno de 2001 utilizando um impactador de ar de seis estágios Millipore $M$ air $\mathrm{T}^{\circledR}$. Vinte e um gêneros de fungos foram identificados. Foram encontrados grupos morfológicos de bactérias bastonetes Gram positivos e negativos e cocos Gram positivos.

\section{REFERENCES}

Ainsworth, G. C.; Bisby, G. R.; Hawksworth, D. L.; Kirk, P. M.; Sutton B. C. and Pegler, D. N. (1995), Dictionary of the Fungi. $8^{\text {th }}$ ed. Wallingford : CAB International.

Alexopoulos, C. J.; Mims, C. W. and Blackwell, M. (1996), Introductory Mycology. $4^{\text {th }}$ ed. USA : John Wiley and Sons.
ANVISA (2000), Resolução n. 176 de 24 outubro de 2000, Brasília, Brasil. http://www.anvisa.gov.br. Acess 26 jan. 2001.

American Society of Heating, Refrigerating and Air Conditioning Engineers (2000), Indoor air quality: position papers, Atlanta GA. http://www.ashrae.org. Acess 27 sept. 2000.

Baker, D. B. (1989), Social and organization factors in office building-associated illness. Occupational Medicine, 4, 607-624.

Barnett H. L. and Hunter, B. B. (1972), Illustrated Genera of Fungi Imperfect. $3^{\text {rd }}$ ed. New York : MacMillan.

Cooley, J. D.; Wong, W. C.; Jumper, C. A. and Straus, D. C. (1998), Correlation between the prevalence of certain fungi and sick building syndrome. Occupational Environment Medicine, 55, 579-584.

Hood, M. A. (1990), Gram-negative bacteria as aerosols. In: Morey, P. R.; Feeley, J. C. and Otten, J. A. (Eds.). Biological Contaminants in Indoor Environments. American Society for Testing and Materials. Philadelphia, Pennsylvania, USA.

Hoog, G. S. and Guarro, J. (1995), Atlas of Clinical Fungi. Reus, Centraalbureau.

Jensen, P. A. and Schafer, M. P. (1998), Sampling and characterization of bioaerosols. Manual of Analytical Methods. USA : National Institute for Occupational Safety Healthy. pp. 82-112.

Jones, A. P. (1999), Indoor air quality and health. Atmospheric Environment, 33, 4535-4564.

Koneman, E. W. and Roberts, G. D. (1992), Micologia Practica de Laboratório. $3^{\text {rd }}$ ed. Buenos Aires : Medica Panamericana.

Lacaz, C. S.; Porto, E.; Heins-Vaccari, E. M. and Melo, N. T. (1998), Guia para Identificação: fungos, actinomicetos, algas de interesse médico. São Paulo : Sarvier.

Larone, D. H. (1995), Medically Important fungi: a guide to identification. Washington : AMS Press.

Li, W. M.; Lee, S. C. and Chan, L. Y. (2001), Indoor air quality at nine shopping malls in Hong Kong. The Science of the Total Environment, 273, 27-40.

Mcgrath, J. J.; Wong, W. C.; Cooley, J. D. and Straus, D. C. (1999), Continually measured fungal profiles in sick building syndrome. Current Microbiology, 38, 33-36.

Morey, P. R.; Chatigny, M.; Otten, J.; Feeley, J.; Burge, H.; La Force, F. M. and Peterson, K. (1986), Airborne viable microorganisms in office environments: sampling protocols and analytical procedures. Applied Industrial Hygiene, 1, 19-23.

Norbäck, D.; Michel, I. and Widströw, J. (1990), Indoor air quality and personal factors related to the sick building syndrome. Scandinavian Journal of Work, Environment and Health, 16, 121-128. 
Rao, C. Y.; Burge, H. A. and Chang, J. C. S. (1996), Review of quantitative standards and guidelines for fungi in indoor air. Journal Air and Waste Management Association, 46, 899-908.

Silveira, V. D. (1995), Micologia. $5^{\text {th }}$ ed. Rio de Janeiro : Âmbito Cultural.

Toth, C. (1992), Microbial in the overall context of indoor air quality investigation. Proceedings of the Annual IAQ, Conference and Exposition. pp. 255-259.

Vincent, D.; Annesi, I. and Lambrozo, J. (1997), Ventilation system, indoor air quality, and health outcomes in parisian modern office workers. Environmental Research, 75, 100-112.

Wanner, H. U.; Verhoeff, A. P.; Colombi, A.; Flannigan, B.; Gravesen, S.; Mouilleseaux, A.; Papadakis, J. and Seidel, K. (1993), Indoor air quality and its impact on man. Biological Particles in Indoor Environments. Report n. 12. Comission of the European Communities, Brussels, Luxembourg.

World Health Organization (1988), Indoor air quality: biological contaminants. World Health Organization, European Series, n. 31, Copenhagen, Denmark.

Received: April 03, 2003; Revised: August 29, 2003; Accepted: February 19, 2004. 